\title{
Comparison of Teachers' Opinions on Inspections
}

\author{
Ján Bajtoš* \\ Received: April 27, 2019; received in revised form: June 23, 2019; \\ accepted: June 24, 2019
}

\begin{abstract}
:
Introduction: The quality of school depends on a well-functioning school management, managed by the top school managers. It is very important to know the real conditions of the school to be able to provide any effective changes. Especially, it is necessary to know the educational process which can be efficiently determined by an inspection process. The inspection process is present in current pedagogical science and in pedagogical practice which deserves increased attention of all participants in the educational process.

Methods: The study is based on a theoretical analysis of the presented issues and on a research. The findings were analysed, compared, and conclusions were drawn for school practice. We used the following research methods:

- content analysis of the existing literature;

- the quantitative method of gathering data by the medium of a twelveitem questionnaire containing four closed and eight semi-open questions. The questionnaire contained data necessary to process and evaluate the questionnaire, these were inserted as the last question;

- statistical data processing methods.

Results: New times bring a new style of management and a new understanding of the inspecting activity, which creates a partnership between the student and the teacher. It is to promote mutual understanding between them, based on the principles of democracy. Innovations in the educational practice also affect the realization of inspecting activities. The aim of managers, as well as inspectors, is to promote inspections not only as a tool for evaluating the teaching process but also as methodological help for teachers. The goal of our research was to map the state of the inspecting activity in selected high schools and to find out about the changes in teachers' opinions on inspecting activities over the twenty-year horizon. We cannot generalize our findings for schools of all kinds as only 88 respondents (44 respondents participated in the 1998 research and 44 respondents in the 2017 research) took part in our research.
\end{abstract}

Discussion: Managing the educational process and taking the responsibility for its quality are among the basic duties of the school

Ján Bajtoš, DTI University, Department of School Didactics, Dubnica nad Váhom, Slovakia; bajtos@dti.sk 


\section{Acta Educationis Generalis \\ volume 9, 2019, issue 2}

management and in the conditions of the Slovak Republic, as it follows from Act no. 596/2003 on state administration in education and school self-government as last amended. Supervising school leadership is one of the fundamental means of feedback that allows the study of the level of educational and training results, the fulfillment of the conceptual development of school, and the fulfillment of the tasks in the short-term school plan. The objective of the principal of the school is to obtain objective information about the level and the outcomes of the educational work of the school and, if deficiencies are identified, it is his/her duty to eliminate them. The most important task of the school is to implement the School Educational Program in line with the State Educational Program (SEP), which should take into account the needs of students, the interests of students and their parents, and contribute to improving the processes going on in the school, especially in the educational process. The research revealed that inspections conducted by school managers (the principal, deputies, administrators) are the most beneficial for the work of teachers. This fact was caused by the effort of the school managers to view inspections as a means of personal growth of teachers and not only as a controlling mechanism of teachers' work. This was also confirmed by the research showing that inspections by the members of school management are now clearly focused on emphasizing the positive aspect of teachers' work. This was caused by a shift in the inspectors' perception of the inspecting activities in the period of twenty years - they use them as a teacher-oriented tool.

Limitations: The number of participants in the research sample was one of the methodological limitations of this research. We cannot consider this number to be representative for the purpose of generalizing the results.

Conclusion: In this study, we realized a mutual comparison of attitudes and opinions of teachers regarding inspecting activities. This comparative study, taking into account the twenty-year time span, has shown that the inspectors (school managers) have acquired such methods of evaluating their teachers, which objectively refer of their actual performance, that the most beneficial inspections for teachers' own pedagogical work are the inspections conducted by the members of the school management, that the adherence to pedagogical ethics by the inspectors has an increasing tendency, and that formalism, as well as the subjective evaluation of teacher's work, have a downward tendency and have disappeared from the conclusions of inspections. Based on the research results, it can be concluded that, in the course of two decades, significant changes have taken place in the realization of inspections, both on the part of the inspectors and on the part of the teachers and their perception of inspections.

Key words: educational process, school management, inspection, quality of the educational process. 


\section{Acta Educationis Generalis \\ volume 9, 2019, issue 2}

\section{Introduction}

Modern schools should lead their students towards critical thinking and should develop their problem-solving skills. Nowadays, in the context of education, there has been a permanent effort for improving the quality of provided education and modernization of schools. There are several ways and tools recommended by the European Union to help such modernization, e.g. Multidimensional Ranking Tools, Mobility Promotion Programs, development of School Partnership etc. The technological development has affected today's schools, especially having an impact on the cooperation among schools, which is mainly in the electronic form (email communication, teleports, and other on-line data transfers) and is faster, more efficient and less expensive as well as less time consumptive for the students, who are being referred to as the "NetGeneration". It is necessary to adjust the educational process in schools to these facts. Modern schools involve these qualities: open mindedness, accessibility; flexibility; diversity; quality; cooperation with the public administration, or the private sector; innovation; engagement and cooperation with local or regional associations; competitiveness, measurability; presence, i.e. it means to be there, where there are more parties: school applicants, students, graduates; for example, Facebook, Twitter etc.

In the study, it is demonstrated how the inspectors (e.g. a school principal) could directly affect the quality of their school, and also summarize and organize basic knowledge and experiences about the inspection aimed at the development and the personal growth of teachers. Last but not least, it is one of our goals to present the results of our research, where the aim is to compare the attitudes and opinions of teachers of the selected type of school on the inspection process over a period of twenty years. The aim of the study is to provide readers with the basic information on inspections in relation to improving the quality of the educational process and to offer suggestions on how to solve and conduct the inspection process in specific school practice.

\section{Analysis of the quality of the educational process}

Even the influence of positive psychology has infiltrated into the current modern schools, which brings about new views on education, ourselves, the world around us (Seligman, 2003). A positive model of school is being built, one that supports the advantages and potentials of students by developing their talents and skills to improve the quality of their life in and outside the school. In such schools we can observe changes in their philosophy, a shift from eliminating negative features to developing the best qualities of school, as well as the people inside it. A positive model of schools focuses on an effective diagnostics of students, on uncovering their positive personality features and characteristics, on determining their motivation and long term aspirations, professional preferences and mapping their general and particular intellectual potentials. Positive 


\section{Acta Educationis Generalis \\ volume 9, 2019, issue 2}

psychology cultivates students' personalities, especially their intra-mental qualities related to creativity, happiness, positive emotions and regulations of their own lives. Seligman (2003) defines the word "happiness" as joy, a flow (a feeling of happiness that a student may experience when being engaged in creative work, while the student is involved in something at school), cheerfulness, pleasure, satisfaction, serenity, and hope. Positive emotions must be strengthened in secondary school students especially as they enhance the cognitive, physiological, emotional and social aspects of students. Seligman also points out the importance of setting an individual into optimistic level, what encourages students in overcoming obstacles, e.g. in learning. By this means, the students will neither look for excuses nor resign. Here, we can mention Cognitive Learning (Anderson \& Krathwohl, 2001), a new trend in teaching students, based on the research in cognitive psychology.

In an effort to achieve a high school quality, it is necessary to possess knowledge and following analysis of the education process (Kmecová, 2018). Current international trends support the analysis of the educational process, because the quality of this process directly determines the students' achievement. It is possible to find ways of improving the quality and making the educational process more efficient by a thorough analysis of relations in the educational process. The final goal of a structural didactical analysis necessary for managing the education process is the knowledge of the teacher's skills (Siváková, 2016). An instrument for analyzing the quality of education process is a kind of pedagogical observation - the so called inspection. In contrast to some other countries, little attention is paid to this matter, which results in stagnation, even a decline in the quality of the educational process. It is true that school managers are led to conducting inspections, but usually such activity is either underestimated or formalized. The platform for analysis and evaluation of the teaching process is to know the criteria of good teaching. It is quite difficult to unambiguously assess the criteria of good teaching, as these are influenced by several factors. According to G. Rötling (1996), the basic elements of the model of good teaching are:

- conditions for teaching,

- teacher's knowledge and experiences,

- activity of a teacher in the teaching/learning process,

- final results of teaching/learning.

\section{Inspections in the educational process}

The use of inspections in the education process is a tool for systemic evaluation of the education process, except for some other methods (e.g. testing students, increasing the adequacy and topicality of the subject matter, etc.). Inspections are a valuable source of information about the quality of education, based on which we can obtain an immediate (live, experienced) and true (acknowledged 


\section{Acta Educationis Generalis \\ volume 9, 2019, issue 2}

by the inspection authority and captured by the reaction of students) knowledge about the true quality and the method of carrying out the education process, about the behavior of the teacher and his/her students at the lesson etc. The term "inspection" has developed over the years from more or less substantive definitions to a very strict scientific definition applied in the current pedagogical theory and practice.

In the Pedagogic Dictionary by the authors J. Průcha, E. Walterová, and J. Mareš (1998), inspection is defined as "visiting a lesson, aiming to know the state and level of the educational work." One of the preconditions for being successful at managing a school is gathering information. The development of the ways and methods of gathering information about the educational process was in the past and still is - even now at the times of humanization and democratization of our education - fairly underrated. Mainly because the managing pedagogical workers have difficulties in gathering exact data about the educational process as well as their evaluation. Yet, little preparation and little experience with this activity does not absolve them from the obligation to find out about the results of the educational process in schools.

One of the methods of gathering information about the quality of the educational process is conducting inspections. From the methodological point of view, it is one of the methods of observation, i.e. direct sense perception, perception of the educational features, which leads to uncovering important connections, relations and patterns (Bajtoš \& Kašaiová, 2018). Among the characteristic features of observation are: focus on a particular goal, then resolution, objectivity, i.e. assessing criteria of evaluation and interpretation of the observed effects; and recording the results. It is not only about the observation for the purpose of describing a given situation, but mainly about the understanding and interpretation of the core of the observed pedagogical effects.

From the above mentioned it appears that the basic precondition for a proper inspection process is its preparation (planning), where the observer must answer the following questions: What do I observe? Why do I observe it? How to make my observation reliable? After detailed planning, the observer is able to exactly and truly record what was observed and eliminate subjective impressions and opinions. A well planned and correctly carried out inspection contains the basic elements of the observation method, i.e. representativeness of the analyzed sample, objectivity, reliability and consistence. It can be stated, that it fulfills its basic function as one of the components in the system of pedagogical management of the work in a school. It enables gathering basic and important information about the pedagogical activities of a teacher and of the pedagogical work in the whole educational institution. The more exact and objective the information gathered throughout an inspection activity are, the more effective the management of the pedagogical process in the school is. The observation method is used during the inspection activity. The focus is on the didactic 


\section{Acta Educationis Generalis \\ volume 9, 2019, issue 2}

indicator of the quality of the educational process, i.e. the quality of teaching (efficiency of the teacher's activities) and on the quality of learning by students (efficiency of students' activities, level of knowledge, skills and abilities, study results). This means that the quality of the educational process is monitored not only formally, but in real, and in the case of serious shortcomings (delay at lessons, infringement of the curriculum, low quality of teaching, insufficient knowledge of students, etc.), the teacher must face consequences drawn from the observations.

It is not the aim of the observations to gather impressions and opinions, or any other subjective information, it is necessary to transform it into true and objective information. It is important to realize that gathering such information is very difficult and time consuming. It demands a transformation from empirically gathered information, i.e. capture of individual experience to information of descriptive character, i.e. information gathered by comparison and evaluation, to information causal, declarative, which enable to understand a causal connection and applicable effect. The aim and purpose of inspections is the cognition of pedagogical situation in the teaching/learning process in a particular educational institution, or the pedagogical activity of a teacher. Only this kind of cognition can be the starting point for efficient management of the pedagogical work in a school and of the teaching/learning process. Inspections have several advantages when compared with other forms and sources of gathering information. Among the most important are (Bajtoš, 1996):

- spontaneity of an observed situation,

- direct participation in the lesson,

- accessibility,

- independence of knowledge and abilities of respondents,

- relatively higher objectivity.

Nowadays, in the period of development of information-communication technologies, we come across the term virtual inspection. It means watching a video-recording of a lesson taught by another teacher. There are many websites, where we can find similar recordings of authentic lessons and anyone can become an observer of such lessons. One of the disadvantages of a virtual inspection lies in the fact, that it only offers a part of what is happening in the classroom, thus, it is impossible to make a complex picture of the situation. A virtual inspection does have advantages as well, such as the possibility to pause and rewind the recording (Bajtoš \& Kašaiová, 2018).

Each organized activity has its own specific structure. This concerns the inspection process as well. Various recommended stages (phases) of the inspection cycle can be found in the literature on the inspection process. Based on the recommendations of J. Bajtoš (1996) and based on our own observations 


\section{Acta Educationis Generalis \\ volume 9, 2019, issue 2}

of the inspection process, we suggest using the following phases of the inspection process:

- Impulse to conduct inspection. Let's assume that each inspection fulfills all the criteria and principles of the observation method - a human approach to the evaluation activity of a teacher and sufficient pedagogical tact. Usually, among the typical impulses for carrying out an inspection belongs the inner responsibility of the school managers for the quality of the educational process in their schools. The inspection should be reported in advance, in order not to impair friendly relations among colleagues. The situation may become much more uncomfortable, when the impulse to carry out an inspection is based on outer impulses, e.g. complaints by students, parents, or colleagues. For school managers, the author strongly recommends to adjust external stimuli to the framework of a particular teacher's further personality development. There are also cases, when the impulse to an inspection comes from a teacher him/herself, usually, when there is a problem and the teacher is unable to solve it.

- Preparation for inspection and a pre-inspection interview. The inspector should be always well prepared before each inspection. Preparation means being familiar with the basic pedagogical documents (school curriculum), with textbooks and the content of the lesson, as well as the psychologicalpedagogical principles, which will be observed and controlled in the teacher's work. The inspector should find the time needed to make a preinspection interview with the observed teacher. In an informal dialogue, it is important to find out, what the aim and the content of the lesson is, and what topic it will follow. Such an interview serves for determining the basic information about the class, about the students' level of knowledge, about the atmosphere in the inspected class.

- Observation of the teaching/learning process. The period of observing the teaching/learning process is the most difficult technical phase. In order to gather objective, true and undistorted information for directing a teacher's work, own subjectivity must be eliminated. The process can be successful only if the observing person gets familiar with the methodological knowledge of observing pedagogical effects. The inspection, as well as any other scientific method for gathering information, must be well-trained. One of the preconditions for a successful observation is the compliance and execution of requirements of a proper observation: healthy and efficient senses; concentration and focusing on the observed matter; ability of fine qualitative differentiation of observed effects; ability to conduct adequate exact estimates; elimination of bad influences (tiredness, anger, conflicts, illness...); execution of exact records from observation; ability to perceive the observed effects without prejudices or illusions. It is necessary to introduce and explain the role of the inspector truly and acceptably to the 


\section{Acta Educationis Generalis \\ volume 9, 2019, issue 2}

students in the class. The question whether the students are introduced to this matter by the teacher or the inspector is an issue of the pre-inspecting interview. It is essential to use any technique that helps to ease the stress in the classroom during the inspection. When the teacher starts the teaching process, the inspector should keep calm and not disturb the process of teaching. The aim is to observe the typical classroom life and the work of the teacher under normal circumstances. It is appropriate to use a structured observation for observing the activity of the teacher and students in a controlled space, e.g. in a classroom. As this term suggests, the inspector uses fragmented and structured categories of effects. It is possible to prepare an observing tool for such a kind of activity including an exact description and rules on how to identify these effects, how to record and how to evaluate them. This approach helps the objectification of the pedagogical observation (Rötling, 1996).

- Post-inspection interview. A post-inspection interview serves to add information and data, which the inspector was not able to gather during the observation of the educational process or those, which are not available at the time of inspection. By means of the post-inspection interview, all necessary information is gathered. Leading of a post-inspection procedure cannot be coincidental but it must respond to the rules and knowledge that have been empirically acquired and theoretically processed.

- Summary and deduction of the inspection. An inspection is not only a controlling activity, but a kind of cooperation between the inspector and the teacher. The more the teacher trusts the inspector and the more the teacher is persuaded about the objectivity, truth and efficiency, the higher the success of the inspection process is. The deduction must therefore be a result of a responsible and detailed analysis of all the gathered data and information. It is necessary to keep out of subjectivism.

\section{Comparison of research in order to find out about the teachers' opinions on inspections}

The motivation to carry out a research on the inspecting activity in high schools was the authors' interest in this matter and the absence of similar research comparing the opinions of teachers in a time sequence of 20 years in the conditions of Slovak education (Bajtoš \& Kašaiová, 2018). We were interested if there have been any changes in the inspecting activity in particular schools from the teachers' point of view within the period of 20 years.

\subsection{Goals of the research}

The goal of the research was to find out and to compare the opinions on the inspecting activity in selected high schools in two time periods. The first research was carried out in 1998 and the other one in 2017. We analyzed and 


\section{Acta Educationis Generalis \\ volume 9, 2019, issue 2}

compared the inal results of the research focused on determining the opinions on inspecting activities. The main goal of the research was divided into the following partial goals:

- To find out what kinds of inspections are considered the most beneficial for teachers' pedagogical work.

- To determine if the ethics is performed in relation to teachers and the teachers accepting inspections.

\subsection{Methodology and organization of the research}

The research was conducted in two high schools in Slovakia, in the county of Trebišov and was realized based on the quantitative method of gathering data by means of a twelve-item questionnaire containing twelve questions (statements), among which four were closed and eight were semi-open. The questionnaire contained data necessary to process and evaluate the questionnaire, these were inserted as the last question. The teachers were asked by the principals of schools to fill in the questionnaire. The research was conducted in June 1998 and in December 2017. The authors attempted to get the same number of respondents in the selected high schools in 2017 as previously in 1998. The return rate of the questionnaires was $68.13 \%$ in 1998 and $88.00 \%$ in 2017.

\subsection{Results of the research and their interpretation}

3.3.1 Benefits of particular types of inspections for the pedagogic work of a teacher

To find out about the benefits of particular types of inspections for pedagogic work of a teacher, we received answers to the bellow questions included in the questionnaire.

Table 1

Question number 4: State, which types of inspections prevail at your school (you can choose more alternatives):

\begin{tabular}{|c|c|c|c|c|c|}
\hline \multirow{2}{*}{\multicolumn{2}{|c|}{$\underline{\text { Available options }}$}} & \multicolumn{2}{|c|}{$\begin{array}{c}\stackrel{1998}{\text { Frequency }} \\
\end{array}$} & \multicolumn{2}{|c|}{$\begin{array}{c}\underline{2017} \\
\underline{\text { Frequency }}\end{array}$} \\
\hline & & 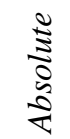 & $\frac{\check{\Xi}}{\check{\Xi}}$ & 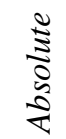 & $\frac{\stackrel{\Xi}{\Xi}}{\check{\Xi}}$ \\
\hline a & None & 0 & 0.00 & 0 & 0.00 \\
\hline b & $\begin{array}{l}\text { By the school managers (principal, vice } \\
\text { principal) }\end{array}$ & 43 & 53.09 & 43 & 38.05 \\
\hline $\mathrm{c}$ & $\begin{array}{l}\text { Mutual (among colleagues teaching the same } \\
\text { or similar subjects) }\end{array}$ & 12 & 14.81 & 20 & 17.70 \\
\hline
\end{tabular}




\begin{tabular}{llcccc}
\hline $\mathrm{d}$ & Of new/beginning teachers & 21 & 25.93 & 26 & 23.01 \\
$\mathrm{e}$ & By experienced teachers & 5 & 6.17 & 24 & 21.24 \\
$\mathrm{f}$ & Other & 0 & 0.00 & 0 & 0.00 \\
\hline
\end{tabular}

In both inquiries, inspections carried out by school managers were marked by the respondents as the most beneficial. In 1998, 53.09\% of respondents expressed this opinion and, in 2017 , it was as much as $38.05 \%$ of respondents. In the research from 2017, we recorded an increase in the benefits of inspections carried out by experienced teachers by $15.07 \%$ as well as an increase of benefits of mutual inspections among colleagues by $2.89 \%$. We assume that this was affected by the effort to see inspections as a way of the personal growth of a teacher - not only as a controlling mechanism of a teacher's work during the teaching unit. One of the most important issues in relation to personal growth is the inspections of novice teachers. In both inquires as much as one quarter of respondents expressed such an opinion. Each novice teacher needs to hear that the activities done and the effort put in the lessons are good. Sometimes, it is necessary to point out the negative aspects of their pedagogical activity. Hereby we suggest using a cooperative approach, which points out that even a novice teacher, as well as the inspector, are colleagues, however, their role is different, yet the experience of both of them is valuable. In practice, we may even use a combined approach, which is partly prescriptive and partly cooperative.

Table 2

Question number 6: The inspections by the head teacher at your school are:

\begin{tabular}{|c|c|c|c|c|c|}
\hline \multirow{2}{*}{\multicolumn{2}{|c|}{ Available options }} & \multicolumn{2}{|c|}{$\begin{array}{l}\underline{1998} \\
\underline{\text { Frequency }}\end{array}$} & \multicolumn{2}{|c|}{$\begin{array}{l}\underline{2017} \\
\underline{\text { Frequency }}\end{array}$} \\
\hline & & 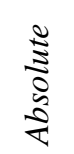 & 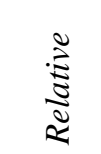 & $\begin{array}{l}\frac{1}{0} \\
0 \\
0 \\
0 \\
0\end{array}$ & $\frac{\sqrt{3}}{20}$ \\
\hline a & $\begin{array}{l}\text { None } \\
\text { Focusing on the teacher's faults }\end{array}$ & 0 & 0.00 & 0 & 0.00 \\
\hline $\mathrm{b}$ & $\begin{array}{l}\text { (the evaluation is based on } \\
\text { reproaching their failures) }\end{array}$ & 15 & 29.41 & 5 & 11.36 \\
\hline c & $\begin{array}{l}\text { Focusing on the positive aspects of } \\
\text { the teacher's work (the teacher's } \\
\text { strengths are emphasized) }\end{array}$ & 31 & 60.79 & 37 & 84.09 \\
\hline d & $\begin{array}{l}\text { Realized by the head teachers only } \\
\text { because of the duty to do so }\end{array}$ & 5 & 9.80 & 2 & 4.55 \\
\hline $\mathrm{e}$ & Other & 0 & 0.00 & 0 & 0.00 \\
\hline
\end{tabular}




\section{Acta Educationis Generalis \\ volume 9, 2019, issue 2}

The obtained data from the research show that inspections focus on the positive aspects of teachers' activities. In the research carried out in 1998, $60.79 \%$ of respondents were in favor of this opinion, in the research from 2017, even more respondents were of the same opinion, particularly $84.00 \%$. It is necessary to point out that the inspections focusing on teachers' strengths have a positive impact on their development, and they increase the quality of their performance at work. In 20 years, there was a $23.30 \%$ increase in the orientation of inspections - focusing on the positive aspects of the teachers' work - and it seems that it is the result of the fact that the inspectors perceive inspections as a tool of the personal growth of teachers. The results of the 2017 survey show a significant drop in inspections focusing on failures by $18.05 \%$ compared to the results in 1998. Inspections oriented on the negative aspects of teachers' work can result in teachers' low self-esteem and fear from the next inspection, as well as to fear of failure. If it does not come to a change of such an approach to inspections, there will hardly occur a change in teachers' pedagogical activity. In such cases the teachers are less open to changes in their pedagogical activities.

Table 3

Question number 11: Order the kinds of inspection according to their benefit to you. The inspections are most beneficial, when they are conducted by:

\begin{tabular}{|c|c|c|c|}
\hline \multirow{2}{*}{\multicolumn{2}{|c|}{ Frequency of answers }} & 1998 & 2017 \\
\hline & & \multicolumn{2}{|c|}{ Frequency } \\
\hline $\mathrm{a}$ & The principal, vice-principal of the school & 1.85 & 1.93 \\
\hline $\mathrm{b}$ & $\begin{array}{l}\text { The principal, vice-principal, if they teach } \\
\text { the same subject }\end{array}$ & 2.55 & 2.98 \\
\hline $\mathrm{c}$ & The chairman of the subject commission & 1.50 & 1.86 \\
\hline d & $\begin{array}{l}\text { A colleague with a long pedagogical } \\
\text { experience }\end{array}$ & 2.20 & 0.98 \\
\hline e & $\begin{array}{l}\text { A colleague with a long pedagogical } \\
\text { experience, when he/she teaches the same } \\
\text { subject }\end{array}$ & 2.80 & 2.25 \\
\hline
\end{tabular}

The respondents indicated the order of the offered options from 1 to 5 . We counted the frequency of each answer. It is obvious from the results that teachers prefer being inspected by a colleague with a long experience, when he/she teaches the same subject. From our experience, we know that it is easier to accept a potential criticism from a colleague than from a principal or a viceprincipal. In 1998, this opinion was expressed by $2.80 \%$ of respondents. In the research from 2017, 2.98\% of respondents preferred the idea of being inspected by the principal or vice-principal of the school, if they teach the same subject. The findings show that teachers consider inspections beneficial, if they are 


\section{Acta Educationis Generalis \\ volume 9, 2019, issue 2}

conducted by an inspector, who teaches the same subject, no matter if it is someone from the school management or a colleague with a long experience in teaching.

3.3.2 Adherence to ethics by the inspector and acceptance of inspections by teachers

In order to identify the contribution of individual kinds of inspections to the pedagogical activity of teachers and to find out, if the ethics is being adhered to by the inspectors, we obtained answers to the following questions in our questionnaire.

Table 4

Question number 7: Do you think that when realizing an inspection, the pedagogical ethics is adhered to by the head teachers (early announcement about the inspection, no interruption of the teaching process, correct and professional evaluation, maintaining the partnership level)?

\begin{tabular}{|c|c|c|c|c|c|}
\hline & & $\begin{array}{l}1 \\
\text { Fre }\end{array}$ & & & incy \\
\hline & options & 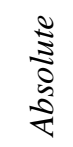 & $\frac{\stackrel{\Xi}{\Xi}}{\approx}$ & 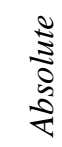 & 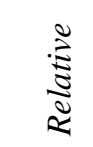 \\
\hline $\mathrm{a}$ & Yes, almost always & 22 & 50.00 & 31 & 70.45 \\
\hline b & Yes, in most cases & 16 & 36.36 & 12 & 27.27 \\
\hline $\mathrm{c}$ & Usually not & 4 & 9.09 & 1 & 2.27 \\
\hline $\mathrm{d}$ & Almost never & 2 & 4.55 & 0 & 0.00 \\
\hline
\end{tabular}

The 1998 survey confirmed that the pedagogical ethics is "almost always" and "in most cases" respected by the inspectors. This opinion was expressed by $86.36 \%$ of the respondents. In the survey from $2017,97.72 \%$ of the respondents believed that the pedagogical ethics is "almost always" and "in most cases" respected by the inspector. It follows from the above that adherence to ethics by inspectors has an increasing tendency and that the inspectors respect the teachers as equal partners. In both investigations that were carried out, there were also teachers who indicated that the inspectors did not follow the pedagogical ethics. In the 1998 survey, it was $13.64 \%$ of respondents, and in 2017 only $2.27 \%$ of respondents. In the work of head teachers, it is necessary to respect this partnership level and keep all the principles of ethics, because only by doing so can both the teachers and the inspector enjoy the mutual benefits of inspections. 


\section{Acta Educationis Generalis \\ volume 9, 2019, issue 2}

Table 5

Question number 8: Based on your personal experiences with inspecting activities at your lessons carried out by the head teacher, do you think that head teachers carry out the inspections:

\begin{tabular}{|c|c|c|c|c|c|}
\hline & & $\begin{array}{r}1 \\
\text { Fre }\end{array}$ & $\begin{array}{l}\frac{98}{\text { ency }} \\
\text { enct }\end{array}$ & Fre & $\begin{array}{l}7 \\
\text { ency } \\
\end{array}$ \\
\hline$\underline{A v a}$ & able options & 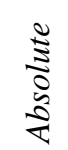 & 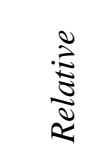 & 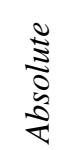 & 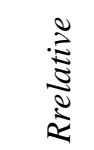 \\
\hline $\mathrm{a}$ & $\begin{array}{l}\text { Great, it is obvious, that they have mastered } \\
\text { the principles of inspecting activities }\end{array}$ & 22 & 50.00 & 31 & 70.45 \\
\hline $\mathrm{b}$ & With a few shortcomings & 6 & 13.64 & 7 & 15.91 \\
\hline $\mathrm{c}$ & I cannot comment on this issue & 15 & 34.09 & 6 & 13.64 \\
\hline $\mathrm{d}$ & With serious deficiencies & 1 & 2.27 & 0 & 0.00 \\
\hline $\mathrm{e}$ & $\begin{array}{l}\text { They have no idea about conducting } \\
\text { inspections }\end{array}$ & 0 & 0.00 & 0 & 0.00 \\
\hline
\end{tabular}

The results of the 1998 survey reveal that teachers are of the opinion that the head teachers have mastered the principles of ethics as "great" and "with a few shortcomings". This opinion was expressed by $63.64 \%$ of the respondents. In the 2017 survey, this opinion was expressed by $86.36 \%$ of teachers. We found out that the quality of the inspecting activities by the inspectors increased and it was also appreciated by the teachers. We were surprised by the finding that there was also a group of teachers who could not comment on this issue. Probably, these teachers either did not know what principles were applied in the inspection process, they did not experience a real post-inspection interview, they did not receive any help from the inspectors, or they might not know about the strengths and weaknesses of their pedagogical work.

\section{Conclusions and recommendations for school practice}

The comparison of research surveys enables us to formulate the following conclusions:

- From the aspect of the educational work of teachers, the inspections conducted by school managers are the most beneficial. This fact was caused by the effort of the school managers to view the inspections as a means of personal growth of the teacher and not only as a control mechanism of the teachers' work. This was also confirmed by the surveys showing that the inspections carried out by the school management are now clearly focused on emphasizing the positive aspects of teachers' work. This was caused by a shift in the inspectors' perception of the inspections - they see it as a 


\section{Acta Educationis Generalis \\ volume 9, 2019, issue 2}

teacher-oriented tool. Teachers also positively evaluate inspections conducted by their colleagues with longer experience who teach the same subject, as they are able to accept a possible criticism from their colleagues better. The findings show that teachers find the most beneficial for their further teaching practice those inspections, which are conducted by teachers teaching the same subject, whether the inspector is in the position of a school manager or is only an experienced teacher.

- Surveys show that adherence to pedagogical ethics has an increasing tendency in inspections, and hence, the inspectors respect teachers as equal partners. Respondents noted that pedagogical ethics was almost always, or in most cases, respected by the inspectors. This fact was justified by further information from the most of respondents who indicated that the inspectors followed the principles of performing an inspecting activity excellently or with only minor deficiencies. We can assume that the quality of the inspecting activities increases and this fact is also appreciated by the teachers. However, among respondents, there is still the opinion that respondents refuse inspections because of their unwillingness to be controlled. We think that the tendency to refuse inspections comes from bad experiences of teachers, especially during the post-inspection interview. The head teachers only use formal evaluation criteria that do not provide a sufficient amount of true and valuable information about teachers' pedagogical work.

Based on the outcomes of the surveys, the following recommendations can be formulated:

- Inspections by head teachers are beneficial for teachers, for their personal growth. They provide basic information about the work of a teacher, which also serve as a basis for the teacher's evaluation, and evaluation of his/her educational work. We can only come to proper evaluation results on the basis of a thorough knowledge of their day-to-day work and their results that the school managers can most effectively gain from the inspecting activity.

- Based on the respondents' statements, we note that ethics is maintained at the inspections by the inspectors. We recommend to the inspectors, especially during the post-inspection interview, not to emphasize the mistakes and shortcomings in the teacher's work. The inspector's unfair prejudice must not be applied in the post-inspection interview. It is correct to point out the positive and negative aspects of the teacher's work, but it is not right to criticize the personality of the teacher.

- We recommend to carry out inspecting activities according to the yearround schedule of inspections. This way, the work of each teacher can be evaluated more objectively. 


\section{Acta Educationis Generalis \\ volume 9, 2019, issue 2}

\section{Conclusion}

The school management gets much information from the inspections that enable them to get an accurate picture of the pedagogical work of individual teachers and the whole school. The observation method is used during the inspecting activity. Attention is focused on the didactic indicators of the quality of the teaching process, i.e. on the quality of education provided by the teacher - the efficiency of the teacher's activities, and the quality of students' learning - the effectiveness of students' activities, the level of their knowledge, skills and abilities, and the study results. To get as accurate image as possible, inspections must not be conducted spontaneously nor occasionally, but each school must have a school year-long inspection plan, which is a part of the internal-schooling plan. A major problem that persists in the practice of inspections is their spontaneity and no planning. This is often the cause of teachers' negative attitude towards inspections. It is true that the school management should pay more attention to those teachers who achieve poorer pedagogical outcomes or have more serious deficiencies in their work. It is also obvious that classroom observations of novice teachers are on schedules as well. Each teacher should be inspected regularly in order to obtain an objective picture of his/her pedagogical work. It is very demanding to find an objective way of gathering information. Determining the constant number of inspections to get the final picture of teachers' work is useless. It depends on the type of school, the number of classes of students in the school, the composition of the pedagogical staff, it depends on the overall school climate, the level of students and also the quality of school managers. The number of inspections is also influenced by the fact, whether the school manager knows well his/her teachers, whether he/she is new to school, whether there is a permanent staff at school, or if there are a lot of new and novice teachers. It follows from the above that the realization of inspecting activities in schools is a much more complicated process than it may seem at the first sight (Bajtoš \& Kašaiová, 2018). This comparative study, taking into account the twenty-year time span, has shown that the inspectors (school managers) have acquired such methods of evaluating their teachers, which objectively refer of their actual performance; that from the aspect of the teachers' own pedagogical work, the most beneficial inspections are the inspections conducted by the members of the school management; that adherence to pedagogical ethics by the inspector has an increasing tendency; and that formalism - as well as subjective evaluation of teacher's work - have a downward tendency which have disappearedffrom the conclusions of the inspection. 


\section{Acta Educationis Generalis \\ volume 9, 2019, issue 2}

\section{References}

Anderson, L. W., \& Krathwohl, D. R. et al. (2001). A Taxonomy for Learning, Teaching, and Assessing: A Revision of Bloom's Taxonomy of Educational Objectives. New York: Longman.

Bajtoš, J. (1996). Hospitácie ako determinujúci faktor kvality školy. Prešov: Metodické centrum.

Bajtoš, J., \& Kašaiová, M. (2018). Teória a prax hospitácií. Dubnica nad Váhom: Vysoká škola DTI.

Kmecová, I. (2018). Efficiency of Teaching Based on the Comparison of Textbooks. Acta Educationis Generalis, 8(1), 50-62. https://doi.org/10.2478/atd-2018-0003

Průcha, J., Walterová, E., \& Mareš, J. (1998). Pedagogický slovník. Praha: Portál.

Rötling, G. (1996). Hospitácia ako nástroj analýzy a hodnotenia vyučovacieho procesu. Pedagogické rozhl'ady, 2, 2-4.

Siváková, G. (2016). Disciplína ako ciel', prostriedok a výsledok výchovy. Bratislava: IRIS.

Seligman, M. (2003). Opravdové štěstí: pozitivní psychologie v praxi. Praha: Ikar. 